\title{
A yellow head virus gene probe: nucleotide sequence and application for in situ hybridization
}

\author{
Kathy F.-J. Tang*, Donald V. Lightner \\ Department of Veterinary Science and Microbiology, University of Arizona, Tucson, Arizona 85721, USA
}

\begin{abstract}
A portion of the genome of yellow head virus (YHV) of penaeid shrimp was cloned and the cDNA fragment (1161 bp) was designated clone 3-27. The fragment was labeled with digoxigenin and hybridized in situ to tissue sections of YHV-infected Penaeus vannamei. Positively reacting tissues included those of the lymphoid organ, cuticular epithelium, and gills. In addition, connective tissue of hepatopancreas, heart, antennal gland, hematopoietic organ, nerve tract, midgut cecum and muscle reacted to the probe. The probe was highly specific since it hybridized only to tissues from YHVinfected shrimp. It did not react to those of uninfected shrimp or shrimp infected with WSSV (white spot syndrome virus), IHHNV (infectious hypodermal and hematopoietic necrosis virus), or TSV (Taura syndrome virus). The clone was sequenced, and primers were synthesized for rapid detection of YHV in hemolymph using RT-PCR (reverse transcription-polymerase chain reaction). The strand that constituted the viral sequence in the cDNA was also determined via RT-PCR and in situ hybridization with a single-stranded RNA (ssRNA) probe.
\end{abstract}

KEY WORDS: Penaeid shrimp - Yellow head virus - In situ hybridization - RT-PCR

\section{INTRODUCTION}

Yellow head virus was first observed in Thailand in the early 1990s, where it resulted in significant mortality and adversely affected the shrimp culture industry (Flegel et al. 1995). Other YHV-like viruses, such as gill associated virus (GAV) and lymphoid organ virus (LOV), have been reported from penaeid shrimp cultured in Australia (Spann et al. 1995, 1997). The proposed relationship between the Australian YHV-like viruses and YHV was based on histological changes in the infected shrimp and characteristics of the virions by electron microscopy.

YHV was named from the gross sign of a yellow cephalothorax in infected Penaeus monodon. However, other shrimp with YHV infection do not always exhibit a yellow cephalothorax. For example, YHVinfected $P$. vannamei and $P$. stylirostris do not display this sign, but they are pallid when moribund. Histo-

\footnotetext{
•E-mail: fengjyu@u.arizona.edu
}

pathological studies have shown that shrimp with YHV infection display a generalized multifocal to diffuse necrosis, with obvious nuclear pyknosis and karyorrhexis. Basophilic, spherical, cytoplasmic inclusions occur in affected tissues, especially in hemocytes, lymphoid organs, cuticular epithelium, gills, and connective tissue of several organs, including muscles, antennal glands, gonads, hematopoietic organs, nerve tracts, etc. (Lightner 1996).

Examination of thin sections of YHV-infected tissues by transmission electron microscopy (TEM) revealed the presence of enveloped, bacilliform virus particles measuring 160-186 $\times 38-50 \mathrm{~nm}$ in the cytoplasm of infected cells (Chantanachokin et al. 1993). TEM of negatively stained, purified YHV virions revealed spike-studded, enveloped particles measuring 150-170 $\times 40-50 \mathrm{~nm}$ (Wongteerasupaya et al. 1995). The complete virion has an electron-dense nuclear core that measures 20 to $30 \mathrm{~nm}$ in diameter and is surrounded by a trilaminar envelope (Nadala et al. 1997).

The YHV genome is RNase sensitive, which suggests that it is a single-stranded RNA (ssRNA) virus 
(Wongteerasupaya et al. 1995). Using SDS-PAGE gel to analyze viral structural proteins, 4 polypeptides of $170,135,67$ and $22 \mathrm{kDa}$ were found. The $135 \mathrm{kDa}$ polypeptide was glycosylated and was likely to be the viral glycoprotein (Nalada et al. 1997). Based on size, bacilliform morphology, cytoplasmic replication, and the fact that it was an ssRNA virus, YHV was proposed to be a member of the Rhabdoviridae (Nadala et al. 1997).

Traditional methods for the diagnosis of yellow head disease are based on clinical signs and histopathology. These methods are not highly specific and are not useful for detecting the early stages of infection or asymptomatic carriers. Therefore, more sensitive and specific methods are needed. This report describes cloning of YHV genomic cDNA and its application as a gene probe for in situ hybridization. In addition, sequence information from the cDNA was used to develop an RT-PCR detection technique that emploved aliquots of shrimp hemolymph as the source of viral RNA template.

\section{MATERIALS AND METHODS}

YHV isolate and propagation in penaeid shrimp. The isolate of YHV used in this study was obtained in 1993 from farm-raised Penaeus monodon in Thailand and maintained at the University of Arizona by continuous transfer in $P$. vannamei. The inoculum was prepared from a homogenate of infected tissues (cephalothoraces) in TN buffer $(0.02 \mathrm{M}$ Tris- $\mathrm{HCl}, \mathrm{pH} 7.2,0.4 \mathrm{M}$ $\mathrm{NaCl}$ ). The tissue homogenate was then diluted with $2 \%$ saline and injected into the muscle of healthy $P$. vannamei. The inoculated shrimp were maintained in seawater at 26 to $28^{\circ} \mathrm{C}$. When the shrimp became moribund, hemolymph samples were drawn and frozen at $-70^{\circ} \mathrm{C}$ for subsequent virus purification or RT-PCR. The cephalothoraces were fixed in Davidson's AFA (Bell \& Lightner 1988) for 24 to $48 \mathrm{~h}$ then changed to $70 \%$ ethanol for storage prior to histological preparation.

Virus purification. Collected hemolymph was frozen and thawed 3 to 4 times to release cell-associated virions from hemocytes, then centrifuged to remove cellular debris at $3000 \times g$ for $30 \mathrm{~min}$ at $4^{\circ} \mathrm{C}$. The supernatant was centrifuged at $100000 \times g$ at $4^{\circ} \mathrm{C}$ for $1 \mathrm{~h}$ to pellet the virions. The viral pellet was resuspended in TN buffer and further purified on a 15 to $35 \%$ Renografin density gradient at $153200 \times g$ for $1 \mathrm{~h}$. The viral band was visualized by top illumination and collected through a fraction collector. The fractions containing viral particles were centrifuged at $100000 \times g$ for $1 \mathrm{~h}$ to remove the Renografin. The virus pellet was resuspended in TN buffer. Purified viral particles were negatively stained on carbon-collodium-coated grids with sodium phosphotungstate $(2 \%)$ and examined under a Philips CM 12S transmission electron microscope.
Viral RNA extraction and cDNA synthesis. Purified viral particles were mixed with a TRIzol LS reagent (Life Technologies, MD, USA) in accordance with the manufacturer's protocol. The purified RNA was resuspended in DEPC (diethylpyrocarbonate)-treated water and stored at $-70^{\circ} \mathrm{C}$. The amount of RNA was quantified by a spectrophotometer at $U_{260}$. CDNA was synthesized with the SuperScript Choice System (Life Technologies). Prior to cDNA synthesis, the RNA was denatured at $70^{\circ} \mathrm{C}$ for $10 \mathrm{~min}$, followed by a quick chilling on ice. Random hexamer was used to prime cDNA synthesis by SuperScript II RT (RNase $\mathrm{H}^{-}$Moloney murine leukemia virus reverse transcriptase). The synthesis of the first strand of cDNA was performed at $42^{\circ} \mathrm{C}$ for $1 \mathrm{~h}$. Then, the second strand of cDNA was synthesized with a mixture of Escherichia coli DNA polymerase I, RNase $\mathrm{H}$ and $E$. coli DNA ligase at $16^{\circ} \mathrm{C}$ for $2 \mathrm{~h}$. EcoR I adaptors were added to the ends of the CDNA followed by ligation into the dephosphorylated EcoR I site of a plasmid (pSport I, Life Technologies). The recombinant plasmid was transformed into competent $E$. coli $\mathrm{DH} 5 \alpha$ and clones containing cDNA inserts were selected with IPTG (isopropylthio- $\beta$-Dgalactoside) and Xgal (5-bromo-4-chloro-3-indolyl- $\beta$ D-galactoside) in accordance with standard procedures (Sambrock et al.1989).

DNA sequencing. Purified plasmid DNA was sent to the DNA Sequencing Lab, Division of Biotechnology, University of Arizona. DNA was sequenced with a PRISM Ready Reaction DiDeoxy Terminator Cycle Sequencing kit from Applied Biosciences.

DNA labeling. The inserted cDNA fragment was labeled with digoxigenin-11-dUTP in a PCR reaction. The labeling mixture included $10 \mathrm{mM}$ Tris- $\mathrm{HCl}$, pH 8.3, $50 \mathrm{mM} \mathrm{KCl}, 0.165 \mathrm{mM}$ dTTP, $0.2 \mathrm{mM}$ dATP, $0.2 \mathrm{mM} \mathrm{dCTP}, 0.2 \mathrm{mM}$ dGTP, $0.035 \mathrm{mM}$ digoxigenin11-dUTP, $2 \mathrm{mM} \mathrm{MgCl} 2,0.3 \mu \mathrm{M}$ primer, template DNA ( $1 \mathrm{ng} \mathrm{\mu l}^{-1}$ ), and $50 \mathrm{U} \mathrm{ml}^{-1}$ of AmpliTaq Gold (PerkinElmer, NJ, USA). The primers were YHV1051F (5'-ACA TCT GTC CAG AAG GCG TC-3') and YHV1051R (5'-GGG GGT GTA GAG GGA GAG AG-3'). The amplification was performed in a thermocycler (GeneAmp 480, Perkin-Elmer) with the following cycle parameters: initial denaturation at $94^{\circ} \mathrm{C}$ for $10 \mathrm{~min}$, followed by 50 cycles of $94^{\circ} \mathrm{C}$ for $1 \mathrm{~min}, 55^{\circ} \mathrm{C}$ for $1 \mathrm{~min}$, $72^{\circ} \mathrm{C}$ for $2 \mathrm{~min}$, and a final extension at $72^{\circ} \mathrm{C}$ for $7 \mathrm{~min}$. The digoxigenin-labeled DNA probe was precipitated with ethanol, resuspended in $\mathrm{H}_{2} \mathrm{O}$, and stored at $-20^{\circ} \mathrm{C}$.

In situ hybridization. Cephalothoraces of YHVinfected shrimp were fixed in Davidson's AFA for 24 to $48 \mathrm{~h}$. Alternatively, shrimp were fixed in a neutralbuffered, modified Davidson's fixative (called RFfixative) (Hanson et al. 1997). The fixed shrimp were processed and embedded in paraffin using standard histological methods. Four $\mu \mathrm{m}$ thick sections were cut, 
and mounted on Superfrost Plus slides (Fisher Scientific, PA, USA). Prior to hybridization, the sections were incubated at $65^{\circ} \mathrm{C}$ for $45 \mathrm{~min}$, then deparaffined in Hemo de (Fisher Scientific), and rehydrated through an ethanol series to water. Sections were digested with proteinase $\mathrm{K}\left(100 \mu \mathrm{g} \mathrm{ml} \mathrm{m}^{-1}\right.$, in $50 \mathrm{mM}$ Tris $-\mathrm{HCl}$, $\mathrm{pH} 7.4,10 \mathrm{mM} \mathrm{NaCl} 1 \mathrm{mM}$ EDTA) for $15 \mathrm{~min}$ at $37^{\circ} \mathrm{C}$, followed by postfixation in formaldehyde $(0.4 \%)$ for $5 \mathrm{~min}$. The sections were rinsed in $2 \times \mathrm{SSC}$ (standard saline citrate), then prehybridized with $500 \mu \mathrm{l}$ of hybridization solution ( $4 \times$ SSC, $50 \%$ formamide, $1 \times$ Denhardt's, $0.25 \mathrm{mg} \mathrm{ml}^{-1}$ yeast RNA, $0.5 \mathrm{mg} \mathrm{ml}^{-1}$ salmon sperm DNA, $5 \%$ dextran sulfate) at $42^{\circ} \mathrm{C}$ for $30 \mathrm{~min}$. For hybridization, the sections were overlaid with $250 \mu \mathrm{l}$ of hybridization solution containing a digoxigenin-labeled probe $\left(20\right.$ to $40 \mathrm{ng} \mathrm{ml}{ }^{-1}$ ) at $42^{\circ} \mathrm{C}$ overnight. The next day, sections were washed as follows: $2 \times \mathrm{SSC}$ once for $30 \mathrm{~min}$ at room temperature; $1 \times \mathrm{SSC}$ twice for $5 \mathrm{~min}$ at $37^{\circ} \mathrm{C} ; 0.5 \times \mathrm{SSC}$ twice for $5 \mathrm{~min}$ at $37^{\circ} \mathrm{C}$. The sections were then incubated with sheep anti-digoxigenin-alkaline phosphatase conjugate (Boehringer Mannheim, Germany) at $37^{\circ} \mathrm{C}$ for $30 \mathrm{~min}$. They were then washed with $0.1 \mathrm{M}$ Tris- $\mathrm{HCl}, \mathrm{pH} 7.5,0.15 \mathrm{M}$ $\mathrm{NaCl}$ twice for $10 \mathrm{~min}$ at room temperature and rinsed with $0.1 \mathrm{M}$ Tris- $\mathrm{HCl}, \mathrm{pH} 9.5,0.1 \mathrm{M} \mathrm{NaCl}$. The sections were incubated with NBT (nitroblue tetrazolium) and BCIP (5-bromo-4-chloro-3-indoyl phosphate) in the dark for 1 to $2 \mathrm{~h}$. After color had developed, the sections were counter-stained with Bismarck Brown Y $(0.5 \%)$, dehydrated through a series of ethanol and Hemo de, and then mounted with coverslips and Permount (Fisher Scientific). Tissue sections from WSSVinfected shrimp were heat-treated for $10 \mathrm{~min}$ at $80^{\circ} \mathrm{C}$ after the addition of probe.

Reverse transcription and PCR (RT-PCR). The onetube GeneAmp EzrTth RNA PCR kit (Perkin-Elmer) was used for RT-PCR. Total RNA extracted from hemolymph was incubated at $70^{\circ} \mathrm{C}$ for $10 \mathrm{~min}$ and reverse transcribed at $60^{\circ} \mathrm{C}$ for $30 \mathrm{~min}$. The PCR reaction was initiated at $94^{\circ} \mathrm{C}$ for $2 \mathrm{~min}$, followed by 40 cycles of PCR $\left(94^{\circ} \mathrm{C}\right.$ for $45 \mathrm{~s}$, and $60^{\circ} \mathrm{C}$ for $45 \mathrm{~s}$ ) ending with $60^{\circ} \mathrm{C}$ for $7 \mathrm{~min}$. Primers used for the RT-PCR were oligonucleotides YHV273F (5'-CAA GAT CTC ACG GCA ACT CA-3') and YHV273R (5'-CCG ACG AGA GTG TTA GGA GG-3'). These primers generated a predicted 273 bp DNA fragment after PCR. An aliquot of the RT-PCR product was analyzed by $1.6 \%$ agarose gel electrophoresis.

For determination of the viral sequence, hemolymph was collected from YHV-infected shrimp and centrifuged at $4000 \times g$ ) for 15 min to remove hemocytes and cell debris. RNA was extracted from the cell-free supernatant with TRIzol LS reagent, resuspended in the DEPC-treated water and stored at $-70^{\circ} \mathrm{C}$. One primer (either YHV273F or YHV273R) was used during the $\mathrm{RT}$ reaction at $72^{\circ} \mathrm{C}$ for $30 \mathrm{~min}$, followed by $94^{\circ} \mathrm{C}$ inactivation of the reverse transcriptase activity for 2 min. The other primer was then added and 40 cycles of PCR were then performed as described above.

Preparation of digoxigenin-labeled ssRNA probes and in situ hybridization. Digoxigenin-labeled RNA probe was synthesized with digoxigenin-11-UTP (Boehringer Mannheim) and a MAXIscript kit (Ambion, TX, USA) in accordance with the supplied protocol. The Pst I-linearized plasmid DNA from clone 3-27 was used with SP6 RNA polymerase to synthesize one strand, and the Sma I-linearized plasmid was used with $\mathrm{T} 7$ RNA polymerase to create the opposite strand. In situ hybridization with the digoxigenin-labeled ssRNA probes was performed at $50^{\circ} \mathrm{C}$ for overnight with the same hybridization buffer described for in situ hybridization using the digoxigenin-labeled double-stranded DNA probe. The concentration of digoxigenin-labeled

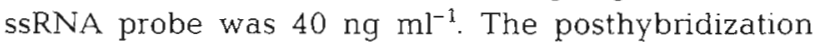
washes were carried out as follows: $2 \times \mathrm{SSC}$ once for $30 \mathrm{~min}$ at room temperature; RNase $\mathrm{A}\left(20 \mu \mathrm{g} \mathrm{ml}{ }^{-1}\right.$, in $2 \times \mathrm{SSC}$ ) digestion for $30 \mathrm{~min}$ at $37^{\circ} \mathrm{C} ; 1 \times \mathrm{SSC}$ twice for $5 \mathrm{~min}$ at $37^{\circ} \mathrm{C} ; 0.5 \times \mathrm{SSC}$ twice for $5 \mathrm{~min}$ at $37^{\circ} \mathrm{C}$. The subsequent reaction with sheep anti-digoxigeninalkaline phosphatase conjugate and color detection were the same as described above.

\section{RESULTS}

\section{YHV purification and cloning of YHV genomic cDNA}

YHV isolated from hemolymph of infected shrimp was density-gradient purified and negatively stained for TEM examination. The virions were shown to be rod-shaped and enveloped with spike projections on the surface. They appeared to be very fragile since many were damaged and frequently fragmented into 2 pieces. The size of the intact virions measured 154 to $210 \mathrm{~nm}$ by 50 to $57 \mathrm{~nm}$. The mean size was approximately $179 \times 54 \mathrm{~nm}$. These measurements were not rigorously calibrated and this may account for them being slightly larger than those of Wongteerasupaya et al. (1995).

We isolated the YHV genomic RNA from purified viral particles using a single-step guanidium isothiocyanate-acid phenol procedure (i.e. TRIzol LS reagent). The cDNA was synthesized and cloned into the plasmid, pSport I. After cDNA cloning, over 300 clones were collected. A pair of $\mathrm{pUC} / \mathrm{M} 13$ primers in a PCR reaction was used to determine the size of the cloned cDNA inserts. One clone contained an insert of $1.1 \mathrm{~kb}$ and was designated 3-27. It was labeled with digoxigenin-11-dUTP in a PCR reaction using $\mathrm{pUC} / \mathrm{M} 13$ primers, so the labeled DNA fragment included an 
additional 234 bp from the cloning vector (pSport I). This labeled cDNA fragment was used as a probe for in situ detection of YHV. It hybridized to YHV-infected shrimp tissues and not to tissues of uninfected shrimp. This clone was subsequently sequenced since it appeared to contain YHV genomic cDNA.

\section{Sequence of clone 3-27 cDNA insert}

The insert of clone 3-27 was characterized by restriction enzyme mapping and nucleotide sequencing (Fig. 1). The sequence of the $1161 \mathrm{bp}$ insert was compared with that of a YHV sequence previously published (135 bp. Wongteerasupaya et al. 1997) and it was found that $84 \mathrm{bp}$ at the end (close to the T7 promoter site) of the 3-27 cDNA insert overlapped with the reported 135 bp cDNA fragment.

\section{In situ hybridization with a digoxigenin-labeled dsDNA YHV probe}

A pair of primers (YHV1051F/R) was designed from the sequence of the YHV cDNA insert to prepare a 1051 bp labeled YHV cDNA probe by PCR. This digoxigenin-labeled probe did not contain any sequence from the cloning vector. It was hybridized in situ to tissue sections of YHV-infected shrimp. In general, the lymphoid organ, cuticular epithelium and gills showed the most pronounced positive hybridization reactions. Intense blue-purple precipitates appeared in the outer periphery of stromal matrix cells in the lymphoid organ tubules, but none appeared in the inner layer of stromal matrix cells or in the lumen-lining, endothelial cells. The connective tissue between the tubules also exhibited a positive reaction to the YHV probe (Fig. 2A). $H \& E$ staining of lymphoid organs revealed multiple foci of necrosis marked by pyknotic and karyorrhectic nuclei (Fig. 2B). In the stomach, the cuticular epithelium and underlying spongy connective tissue reacted to the YHV probe. The epithelial cells appeared to give a stronger positive reaction, in terms of intensity, than did the subcuticular connective tissue cells (Fig. 2C). The reaction of muscle cells surrounding the stomach was negative, but connective tissue in the muscle bundles reacted positively (data not shown). In gill tissues, afferent/efferent vessels and epithelial and pillar cells of gill filaments gave strong positive reactions (Fig. 2D).

The connective tissues associated with several organs examined were positive. In the hepatopancreas (Fig. 2E), the tubules did not react with the probe, but the myoepithelial cells of interstitial connective tissues that surrounded the tubules were positive and the connective tissue capsule of the hepatopancreas was also positive. In the heart (Fig. 2F), the myocardial cells were negative, but the connective tissue surrounding the heart was positive. Fixed phagocytes were also positive to the probe. In the antennal gland (Fig. 2G), epithelial cells in the tubules gave a negative reaction, while surrounding fibrous connective tissues were positive. In the nerve tracts (Fig. $2 \mathrm{H}$ ), glial cells reacted to the YHV probe. In the hematopoietic organ (Fig. 2I), connective tissues were positive, while the parenchymal cells were negative. Also, epithelial folds of the midgut cecum (Fig. 2J) were negative and only submucosal connective tissue was positive. No positive reaction was seen in any of the tissues prepared from healthy, uninfected shrimp or from the TSV-, WSSV-, or IHHNV-infecied shrimp.

\section{RT-PCR}

Another pair of primers (designated as $Y H V 273 F / R$ ) was designed from the YHV CDNA insert to generate a 273 bp DNA fragment after RT-PCR. For this RT-PCR, a total RNA was isolated from hemolymph of YHVinfected shrimp and it generated a predicted $273 \mathrm{bp}$ DNA fragment (Fig. 3). Hemolymph without prior RNA purification was also used successfully as a template to generate the 273 bp DNA fragment in RT-PCR reactions. The $273 \mathrm{bp}$ PCR fragment was not obtained with hemolymph from uninfected shrimp.

\section{Determination of viral strand sequence}

The primers YHV273F/R were used in RT-PCR reactions to determine which strand of the cDNA constituted a copy of the viral strand. When RNA isolated from cell-free hemolymph was used as the viral RNA template, only primer YHV273R annealed to the viral RNA and initiated the synthesis of cDNA for the subsequent successful PCR reaction to generate the characteristic $273 \mathrm{bp}$ YHV amplicon. No amplicon was obtained when primer YHV273F was used in the RT step of the reaction (Fig. 4). The $T_{m}$ values of primers YHV273F and YHV273R were very close $\left(64.1^{\circ} \mathrm{C}\right.$ and $63.7^{\circ} \mathrm{C}$, respectively) so that differential annealing of YHV273R and YHV273F to the RNA template could not be used to explain the difference in the RT-PCR result for the 2 primers. In addition, positive in situ hybridization (Fig. 5A) occurred only with a digoxigenin-labeled ssRNA probe product from T7 RNA polymerase (same sequence as the bottom strand of YHV cDNA shown in the Fig. $1 \mathrm{~B}$ but with $U$ substituted for $\mathrm{T}$ ). There was negative in situ hybridization (Fig. 5B) with an ssRNA probe product synthesized by SP6 RNA polymerase (i.e. the strand with a sequence 
the same as the upper strand of cDNA shown in the Fig. 1B but with $\mathrm{U}$ substituted for T). Both the RT-PCR results and the in situ hybridization results indicated that the upper strand of cDNA shown in Fig. 1B corresponded to the viral sequence.

\section{Sequence analysis}

The 3-27 YHV genomic cDNA sequence was translated into 6 reading frames. The viral strand (i.e. the upper strand shown in the Fig. 1B) contained relatively

A

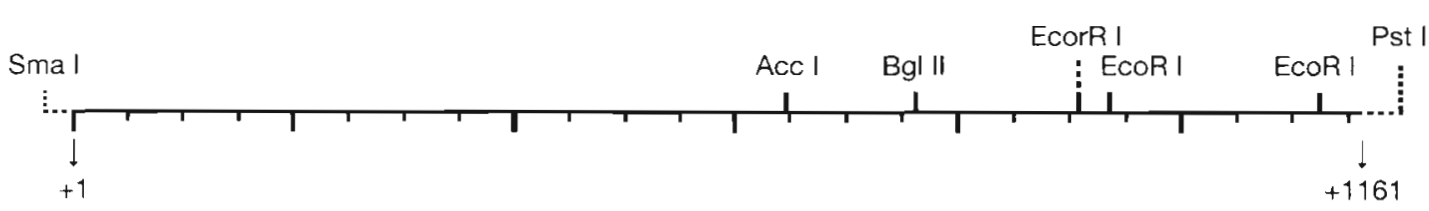

B

\begin{tabular}{|c|c|c|c|c|c|c|}
\hline 1 & $\begin{array}{l}\text { TCAAGATGGA } \\
\text { AGTTCTACCT }\end{array}$ & $\begin{array}{l}\text { CATCTTCGAC } \\
\text { GTAGAAGCTG }\end{array}$ & $\begin{array}{l}\text { TACACCTACA } \\
\text { ATGTGGATGT }\end{array}$ & $\begin{array}{l}\text { CCTGCTACAC } \\
\text { GGACGATGTG }\end{array}$ & $\begin{array}{l}\text { AAAAGCACAG } \\
\text { TTTTCGTGTC }\end{array}$ & $\begin{array}{l}\text { TCATTCGCAT } \\
\text { AGTAAGCGTA }\end{array}$ \\
\hline 61 & $\begin{array}{l}\text { TACAAGCATG } \\
\text { ATGTTCGTAC }\end{array}$ & & $\begin{array}{l}\text { AACTTCGACA } \\
\text { TTGAAGCTGT }\end{array}$ & $\begin{array}{l}\text { TCACTCCAGA } \\
\text { AGTGAGGTCT }\end{array}$ & $\begin{array}{l}\text { CAACATCTGT } \\
\text { GTTGTAGACA }\end{array}$ & $\begin{array}{l}\text { CCAGAAGGCG } \\
\text { GGTCTTCCGC }\end{array}$ \\
\hline 121 & $\begin{array}{l}\text { TCTATGACTT } \\
\text { AGATACTGAA }\end{array}$ & $\begin{array}{l}\text { CGAGACATAT } \\
\text { GCTCTGTATA }\end{array}$ & $\begin{array}{l}\text { CGTCCCGGCA } \\
\text { GCAGGGCCGT }\end{array}$ & $\begin{array}{l}\text { ITGTGATCC } \\
\text { AACACTAGG }\end{array}$ & $\begin{array}{l}\text { CATCAAAGCT } \\
\text { GTAGTTTCGA }\end{array}$ & $\begin{array}{l}\text { CTCAACGCCG } \\
\text { GAGTTGCGGC }\end{array}$ \\
\hline 181 & $\begin{array}{l}\text { TCACGTATTG } \\
\text { AGTGCATAAC }\end{array}$ & $\begin{array}{l}\text { CATCGAACGT } \\
\text { GTAGCTTGCA }\end{array}$ & $\begin{array}{l}\text { CACTGGTTCT } \\
\text { GTGACCAAGA }\end{array}$ & $\begin{array}{l}\text { CCGCTGGTCT } \\
\text { GGCGACCAGA }\end{array}$ & $\begin{array}{l}\text { CTCACTCTCC } \\
\text { GAGTGAGAGG }\end{array}$ & $\begin{array}{l}\text { TGCGCATCTA } \\
\text { ACGCGTAGAT }\end{array}$ \\
\hline 241 & $\begin{array}{l}\text { TTTACCCACA } \\
\text { AAATGGGTGT }\end{array}$ & $\begin{array}{l}\text { TGAAGACATG } \\
\text { ACTTCTGTAC }\end{array}$ & $\begin{array}{l}\text { ACAATTCATC } \\
\text { TGTTAAGTAG }\end{array}$ & $\begin{array}{l}\text { AGTACAAAGA } \\
\text { TCATGTTTCT }\end{array}$ & $\begin{array}{l}\text { AGCATTCGCA } \\
\text { TCGTAAGCGT }\end{array}$ & $\begin{array}{l}\text { CTCTACACTA } \\
\text { GAGATGTGAT }\end{array}$ \\
\hline 301 & $\begin{array}{l}\text { CAGAATTGAA } \\
\text { GTCTTAACTT }\end{array}$ & & & $\begin{array}{l}\text { ACCAACC } \\
\text { TGGTTGG }\end{array}$ & & $\begin{array}{l}\text { TCAACT } \\
\text { AGTTGA }\end{array}$ \\
\hline 361 & $\begin{array}{l}\text { TCATGCTTGT } \\
\text { AGTACGAACA }\end{array}$ & $\begin{array}{l}\text { CACAGAGCGT } \\
\text { GTGTCTCGCA }\end{array}$ & & $\begin{array}{l}\text { ACATTGACAT } \\
\text { TGTAACTGTA }\end{array}$ & $\begin{array}{l}\text { CGGCACAGGO } \\
\text { GCCGTGTCCC }\end{array}$ & $\begin{array}{l}\text { AGCAGACACC } \\
\text { TCGTCTGTGG }\end{array}$ \\
\hline 421 & $\begin{array}{l}\text { TTCTACACTT } \\
\text { AAGATGTGAA }\end{array}$ & & $\begin{array}{l}\text { CATCACATCA } \\
\text { GTAGTGTAGT }\end{array}$ & $\begin{array}{l}\text { GCTCCGTGTA } \\
\text { CGAGGCACAT }\end{array}$ & & $\begin{array}{l}\text { ACGAA } \\
\text { TGCTT }\end{array}$ \\
\hline 481 & $\begin{array}{l}\text { GTCATGGCCG } \\
\text { CAGTACCGGC }\end{array}$ & & & $\begin{array}{l}\text { GCCTACCAGT } \\
\text { CGGATGGTCA }\end{array}$ & $\begin{array}{l}\text { ATGATAGAGG } \\
\text { TACTATCTCC }\end{array}$ & $\begin{array}{l}\text { TGATTTTCCT } \\
\text { ACTAAAAGGA }\end{array}$ \\
\hline 541 & $\begin{array}{l}\text { TGCAAATACA } \\
\text { ACGTTTATGT }\end{array}$ & $\begin{array}{l}\text { CAGTCACTCA } \\
\text { GTCAGTGAGT }\end{array}$ & $\begin{array}{l}\text { AACTCACGTC } \\
\text { TTGAGTGCAG }\end{array}$ & $\begin{array}{l}\text { AAATACCCTG } \\
\text { TTTATGGGAC }\end{array}$ & $\begin{array}{l}\mathrm{CGA} \\
\mathrm{GCT}\end{array}$ & $\begin{array}{l}\text { STGTG } \\
\text { GACAC }\end{array}$ \\
\hline 601 & $\begin{array}{l}\text { GAACCTGAAG } \\
\text { CTTGGACTTC }\end{array}$ & $\begin{array}{l}\text { AATGCAAAAA } \\
\text { TTACGTTTTT }\end{array}$ & & $\begin{array}{l}\text { AACAGTTACC } \\
\text { TTGTCAATGG }\end{array}$ & $\begin{array}{l}\text { GTCTA } \\
\text { CAGAT }\end{array}$ & $\begin{array}{l}\text { GCTCTG } \\
\text { CGAGAC }\end{array}$ \\
\hline 661 & $\begin{array}{l}\text { ATCTCCATCC } \\
\text { TAGAGGTAGG }\end{array}$ & $\begin{array}{l}\text { AGAAATTCAG } \\
\text { TCTTTAAGTC }\end{array}$ & $\begin{array}{l}\text { CACCTGCGCT } \\
\text { GTGGACCCGA. }\end{array}$ & $\begin{array}{l}\text { CGTCTCATGT } \\
\text { GCAGAGTACA }\end{array}$ & $\begin{array}{l}\text { ATAT } \\
\text { TATA }\end{array}$ & $\begin{array}{l}\text { TCTCAAGCGA } \\
\text { AGAGTTCGCT }\end{array}$ \\
\hline 721 & $\begin{array}{l}\text { GTCTTCAATC } \\
\text { CAGAAGTTAGS }\end{array}$ & $\begin{array}{l}\text { ACTGTCGTGA } \\
\text { TGACAGCACT }\end{array}$ & $\begin{array}{l}\text { CTGTGACCAT } \\
\text { GACACTGGTA }\end{array}$ & $\begin{array}{l}\text { CTTAACTGCA } \\
\text { GAATTGACGT }\end{array}$ & $\frac{C A C G}{G G G C}$ & $\frac{\text { GCAACTCATG }}{\text { CGTTGAGTAC }}$ \\
\hline 781 & $\begin{array}{l}\text { CGCTTCAAGA } \\
\text { GCGAAGTTCT }\end{array}$ & $\begin{array}{l}\text { ATCCACTTTC } \\
\text { TAGGTGAAAG }\end{array}$ & $\begin{array}{l}\text { CAACATTCAG } \\
\text { GTTGTAAGTC }\end{array}$ & $\begin{array}{l}\text { CCAGTCGCAT } \\
\text { GGTCAGCGTA }\end{array}$ & $\begin{array}{l}\text { ACACTAAACT } \\
\text { TGTGATTTGA }\end{array}$ & $\begin{array}{l}\text { ACACGAAGAT } \\
\text { TGTGCTTCTA }\end{array}$ \\
\hline 841 & $\begin{array}{l}\text { CGTCACCTAA } \\
\text { GCAGTGGATT }\end{array}$ & $\begin{array}{l}\text { TCCGTGACCG } \\
\text { AGGCACTGGC }\end{array}$ & $\begin{array}{l}\text { TCTCACACAC } \\
\text { AGAGTGTGTG }\end{array}$ & $\begin{array}{l}\text { ATGGACTTCA } \\
\text { TACCTGAAGT }\end{array}$ & $\begin{array}{l}\text { CCTCAGGTCA } \\
\text { GGAGTCCAGT }\end{array}$ & $\begin{array}{l}\text { AGAGTTCTAC } \\
\text { TCTCAAGATG }\end{array}$ \\
\hline 901 & $\begin{array}{l}\text { GCTACTGAAT } \\
\text { CGATGACTTA }\end{array}$ & $\begin{array}{l}\text { TCATCAATGA } \\
\text { AGTAGTTACT }\end{array}$ & $\begin{array}{l}\text { GTTCAATGAC } \\
\text { CAAGTACTG }\end{array}$ & $\begin{array}{l}\text { GTCGAATTCA } \\
\text { CAGCTTAAGT }\end{array}$ & $\begin{array}{l}\text { AGACACTGAA } \\
\text { TCTGTGACTT }\end{array}$ & $\begin{array}{l}\text { CGGTGATACC } \\
\text { GCCACTATGG }\end{array}$ \\
\hline 961 & $\begin{array}{l}\text { ATTCACTTCA } \\
\text { TAAGTGAAGT }\end{array}$ & $\begin{array}{l}\text { ACCTCACGCA } \\
\text { TGGAGTGCGT }\end{array}$ & $\begin{array}{l}\text { TCCCTATGAC } \\
\text { AGGGATACTG }\end{array}$ & $\begin{array}{l}\text { GCTCTCCTCG } \\
\text { CGAGAGGAGC }\end{array}$ & $\begin{array}{l}\text { AACCTCTACT } \\
\text { TTGGAGATGA }\end{array}$ & $\begin{array}{l}\text { TCCTCCTAAC } \\
\text { AGGAGGATTC }\end{array}$ \\
\hline 1021 & $\begin{array}{l}\text { ACTCTCGTCG } \\
\text { TGAGAGCAGC }\end{array}$ & $\begin{array}{l}\text { GAAATTCAGT } \\
\text { CTTTAAGTCA }\end{array}$ & $\begin{array}{l}\text { GGCAGCATCA } \\
\text { CCGTCGTAGT }\end{array}$ & $\begin{array}{l}\text { GGCGTTATTA } \\
\text { CCGCAATAAT }\end{array}$ & $\begin{array}{l}\text { GTGATCTTGA } \\
\text { CACTAGAACT }\end{array}$ & $\begin{array}{l}\text { CGCTAATTTC } \\
\text { GCGATTAAAG }\end{array}$ \\
\hline 1081 & $\begin{array}{l}\text { AAAAACTACG } \\
\text { TTTTTGATGC }\end{array}$ & & $\begin{array}{l}\text { CGGCATGTCC } \\
\text { GCCGTACAGG }\end{array}$ & $\begin{array}{l}\text { TGTTCTCTCA } \\
\text { ACAAGAGAGT }\end{array}$ & $\begin{array}{l}\text { CTGAATTCCA. } \\
\text { GACTTAAGGT }\end{array}$ & $\begin{array}{l}\text { GCTCTCTCCC } \\
\text { CGAGAGAGGG }\end{array}$ \\
\hline & & & & & & \\
\hline
\end{tabular}

Fig. 1. (A) Restriction enzyme map and (B) nucleotide sequence of the cDNA insert in clone 3-27. (A) The YHV cDNA insert was digested with $A C C$ I $B G I$ II and ECoR I. The positions of restriction sites are $A C C$ I at $+647, B g I$ II at +761 , and EcoR I at +907 , +934, and +1123. Sites of Sma I (-25) and Pst I (+1192) were located upstream and downstream of the cDNA insert, respectively. (B) The SP6 (-119) and T7 (+1230) promoters reside upstream and downstream, respectively, of the starting site (+1) of the cDNA insert. Nucleotides in bold type $(\mathrm{N})$ represent sequences of the PCR primers YHV1051F/R. Underlined nucleotides (N) are the primers YHV273 F/R 

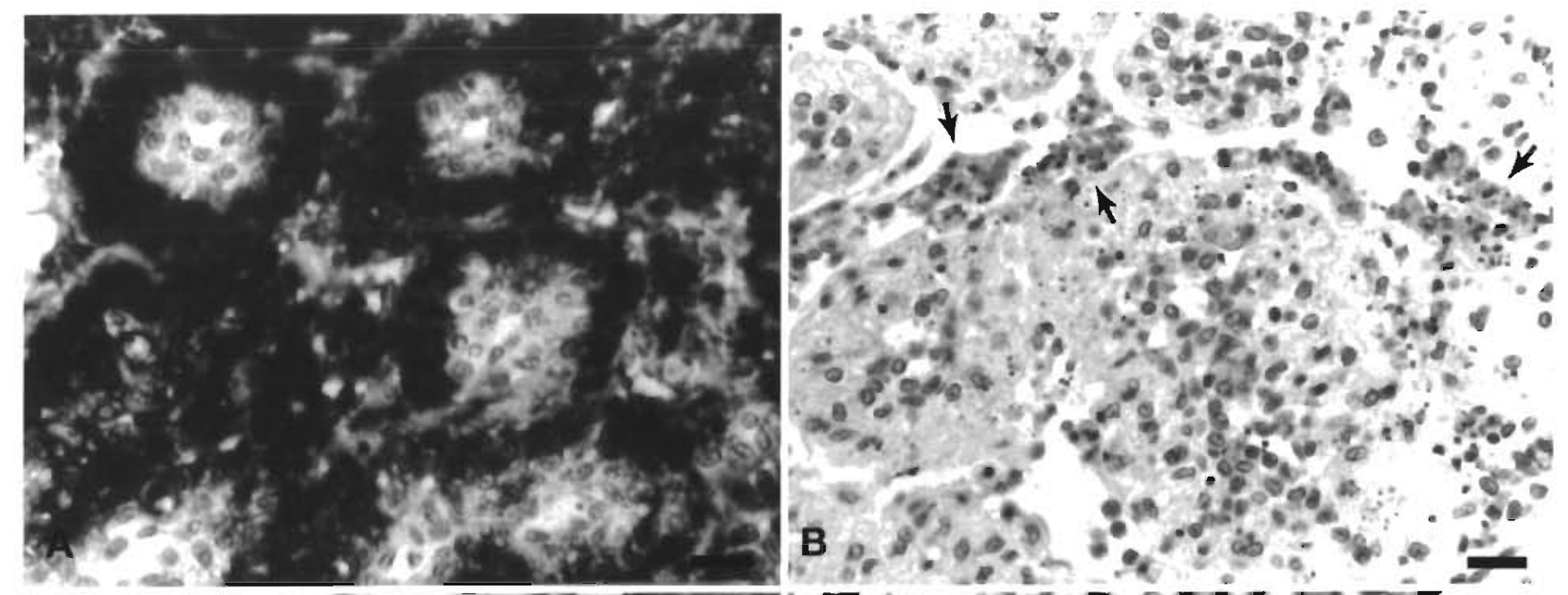

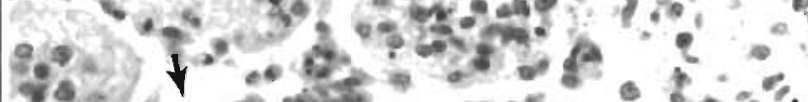

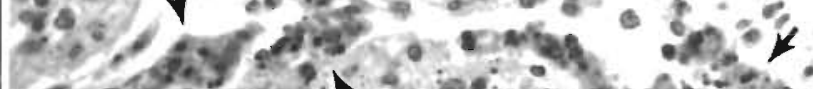

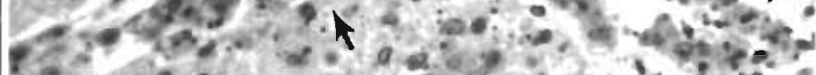

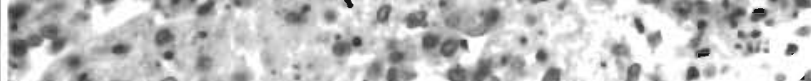

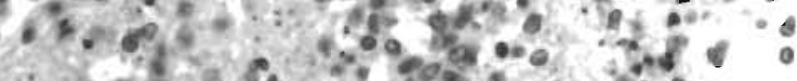

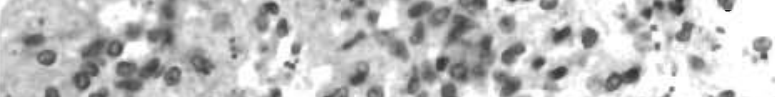

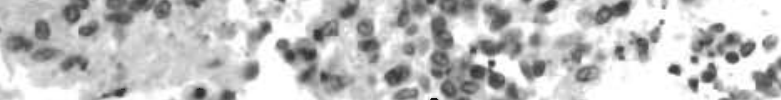

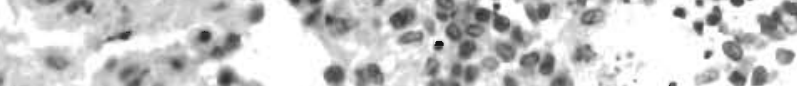

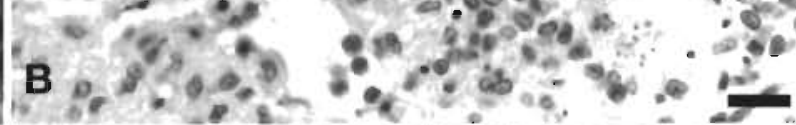

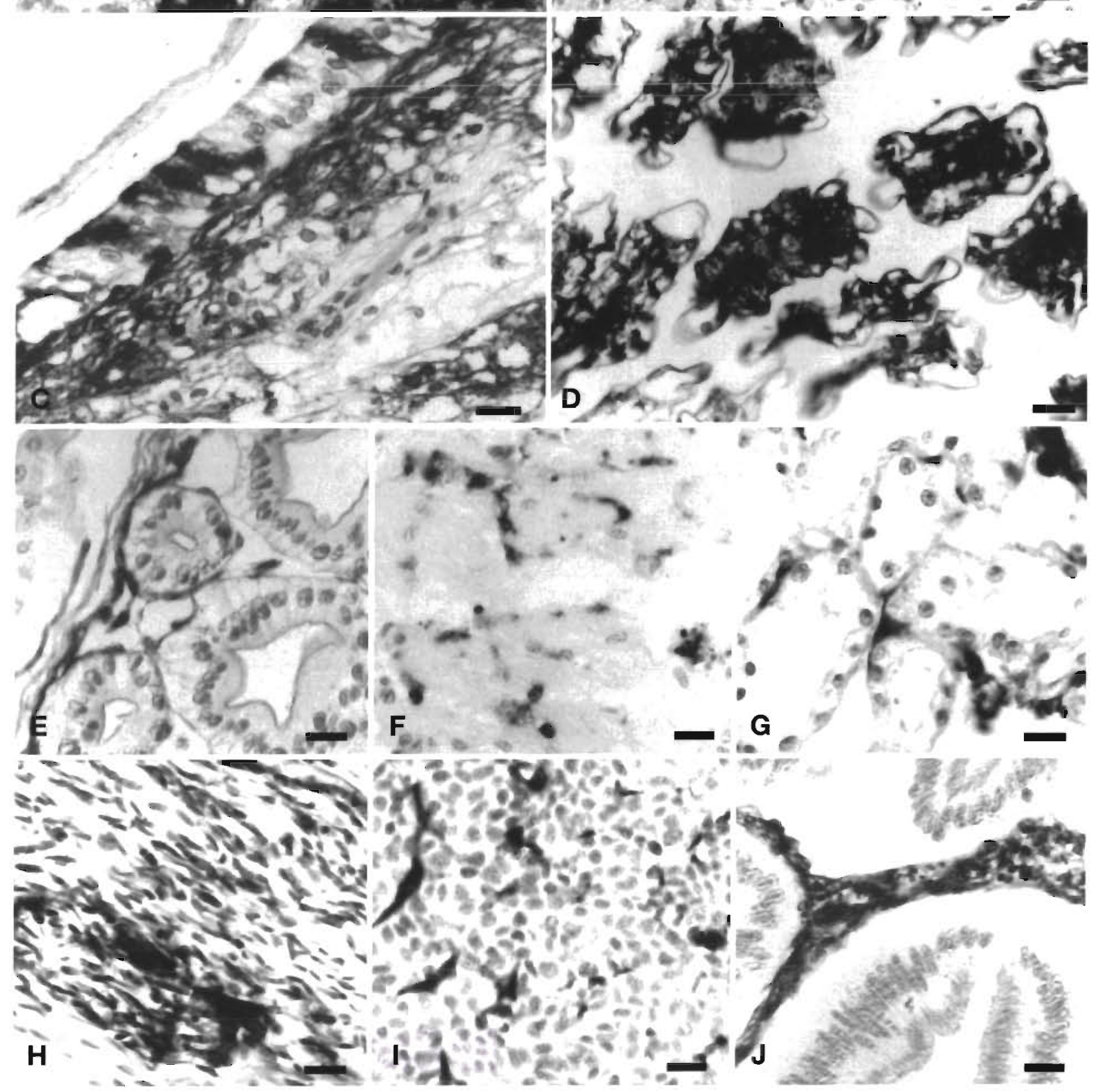


Fig. 2. In situ hybridization of tissue from YHV-infected shrimp with a digoxigenin-labeled dsDNA probe. (A) lymphoid organ; (B) H\&E stained lymphoid organ, with several foci (arrows) containing pyknotic and karyorrhectic nuclei seen throughout the tissue; (C) cuticular epithelium of the stomach; (D) gill tissue; (E) hepatopancreatic tissue; (F) heart; (G) antennal gland; (H) nerve

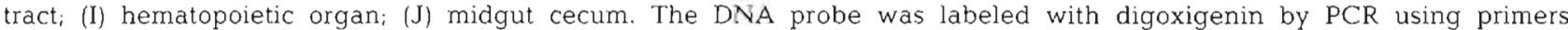
YHV1051F/R with the cDNA insert in clone 3-27 as template. Scale bars $=20 \mu \mathrm{m}$

large open reading frames (226 amino acids [aa] for frame 1 from nucleotide 484 to 1161 and 172 aa for frame 3 from nucleotide 6 to 524). The strand complementary to the viral strand contained no open reading frame larger than 100 aa. This suggested that the viral strand was a sense strand, if the sequenced portion of the YHV genome encoded for a polypeptide. Using the Blast program of Seqlab software (GCG, Genetics Computer Group) to search for homologous sequences in DNA and protein sequence databases, no homologous viral or invertebrate sequences were found.

\section{DISCUSSION}

This report describes the cloning of a portion of YHV genomic cDNA and its successful application as a highly specific gene probe to detect YHV infection by in situ hybridization. The in situ hybridization results were consistent with those based on traditional histology but were more sensitive in that cells with no visible

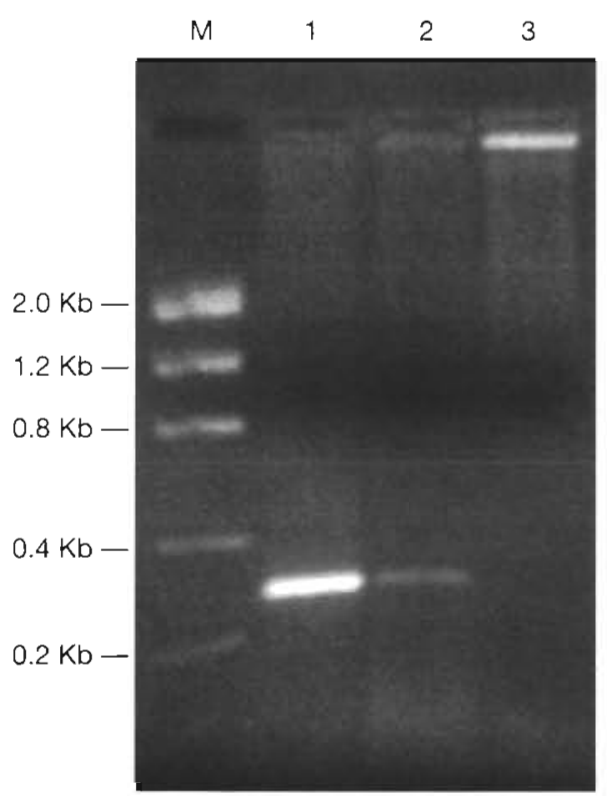

Fig. 3. Detection of YHV by RT-PCR. Lane M: molecular weight marker. Sources of templates were Lane 1: total RNA extracted from $25 \mu \mathrm{l}$ of hemolymph drawn from YHV-infected shrimp; Lane 2: $1 \mu$ of hemolymph (without RNA extraction) from YHV-infected shrimp; Lane 3: $1 \mu \mathrm{l}$ of hemolymph from uninfected shrimp. The oligonucleotides YHV273F/R were used as primers signs of infection by normal histology could be detected with the probe. The use of the digoxigeninlabeled dsDNA probe coupled with alkaline phosphatase detection was simple and practical and the non-radioactive probe could be stored for long periods. The colored precipitate in positively reacting tissues lasts several months without significant fading and the low background allows for unambiguous determination of reaction sites.

In situ hybridization clearly revealed YHV tissue tropism. The lymphoid organ, gills, and cuticular epithelial cells gave the highest viral signal, while connective tissues gave moderate signals. Although the mechanism of YHV tissue tropism is not known, our results

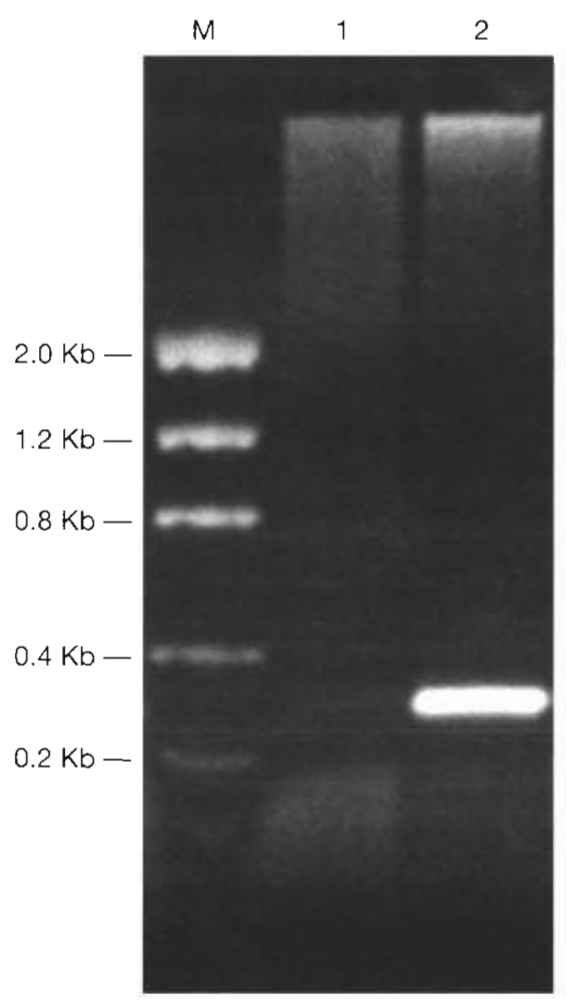

Fig. 4. Determination of viral strand sequence by RT-PCR. Lane: $\mathrm{M}$ : molecular weight marker; Lane 1: oligonucleotide YHV273F used as the primer for the RT reaction; Lane 2: oligonucleotide YHV273R used as the primer for the RT reaction. After the RT reaction, the complementary primer was added prior to PCR amplification as described in the 'Materials and methods'. Total RNA isolated from $25 \mu \mathrm{l}$ of cell-free hemolymph drawn from YHV-infected shrimp was used as the template 

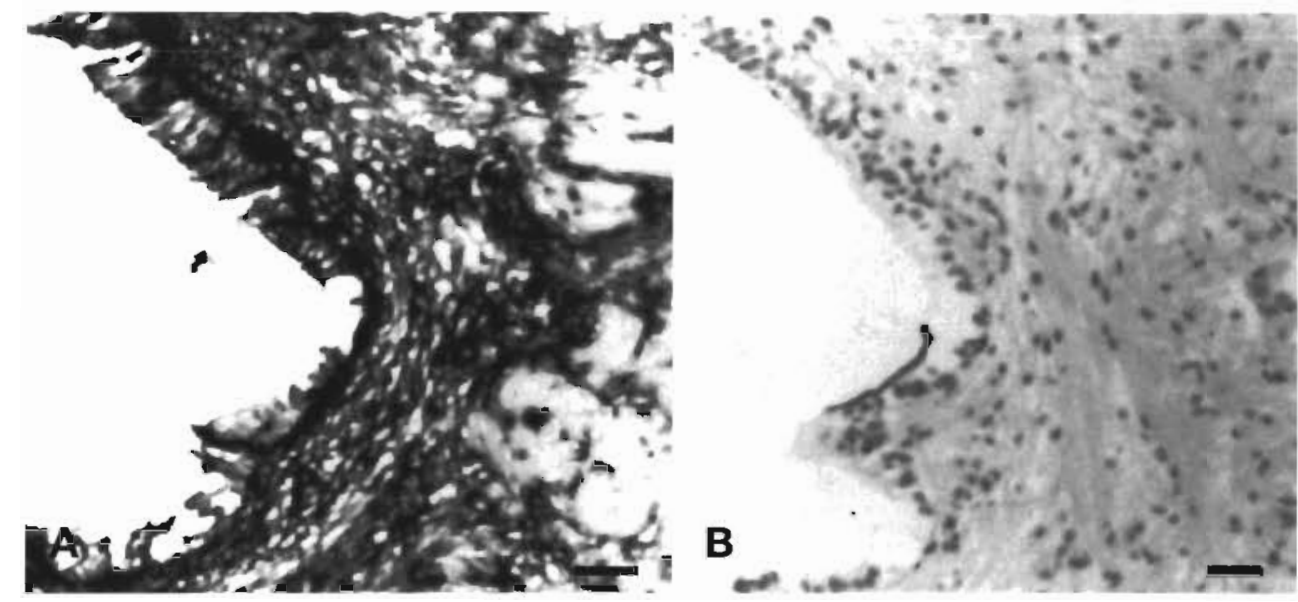

Fig. 5. In situ hybridization with YHV-infected shrimp tissues using single-stranded RNA (ssRNA) probes. (A) Tissue section hybridized with ssRNA synthesized using T7 RNA polymerase and Sma Ilinearized template. (B) Tissue section hybridized with ssRNA synthesized using SP6 RNA polymerase and Pst I-linearized template. Both ssRNA probes were labeled with digoxigenin-11-UTP. The tissue shown is cuticular epithelium of the stomach. Scale bars = $40 \mu \mathrm{m}$

from in situ hybridization correspond to those of Lu et al. (1995) from viral titration in lymphoid organ culture.

For RT-PCR, the use of a small quantity (e.g. $1 \mu \mathrm{l}$ ) of shrimp hemolymph as the viral RNA template eliminated time-consuming RNA purification procedures and provided a rapid, sensitive detection method for YHV using primers for the $273 \mathrm{bp}$ amplicon. In experiments with primers for larger amplicons based on the YHV cDNA clone (i.e. 1051 and 644 bp), less satisfactory results were obtained (data not shown). These larger PCR fragments were not obtained in non-nested RT-PCR reactions. The unsatisfactory results could have resulted from the YHV RNA being fragmented after RNA purification or from the ITth DNA polymerase being less efficient in transcribing larger sizes of YHV RNA. In a nested RT-PCR reaction, the $644 \mathrm{bp}$ PCR amplicon could be obtained when using primers for the $1051 \mathrm{bp}$ amplicon in the first RT-PCR followed by a second round of PCR using inner primers for the 644 bp amplicon. Larger PCR amplicons would facilitate study of sequence variations amongst various YHV isolates.

Our results from RT-PCR, ssRNA in situ hybridization and sequence analysis suggested that $\mathrm{YHV}$ is a positive sense RNA virus. The presence of large open reading frames in 2 additional clones (3-01 and 3-37) also supported this contention (data not shown). If this analysis is correct, then the placement of YHV in the family Rhabdoviridae is doubtful, since it comprises negative sense ssRNA viruses (Murphy et al. 1995). However, the polarity of the viral strand remains to be determined by synthesizing and identifying the polypeptides from the cloned DNA. A search in GenBank did not reveal any sequences homologous to that of the YHV cDNA described herein. This may be due to the fact that very few viral sequences of crustacean viruses have been submitted or that YHV is only distantly related to RNA viruses of other plant, invertebrate or vetebrate groups. We are continuing to screen and analyze clones that contain sequences adjacent to 3-27.

Acknowledgements. This work was supported by the Gulf Coast Research Laboratory Consortium Marine Shrimp Farming Program, CSRS, USDA, under Grant no. 88-38808-3320, The National Marine Fisheries Service (Saltonstall-Kennedy Act), USDC, under Grant No. NA56FD0621, and a special grant from the National Fishery Institue, Washington, DC. We thank Rita Redman for preparation and processing of histological sections, Ken Hanson, Carlos Pantoja, and Qiong Wang for assistance in histological analysis, and Jeff Garza for assistance in preparation of figures.

\section{LITERATURE CITED}

Bell TA, Lightner DV (1988) A handbook of normal penaeid shrimp histology. World Aquaculture Society, Baton Rouge, LA

Chantanachookin C, Boonyaratpalin S, Kasornchandra J Direkbusarakom S, Ekpanithanpong $U$, Supamataya $K$, Sriurairatana S, Flegel TW (1993) Histology and ultrastructure reveal a new granulosis-like virus in Penaeus monodon affected by yellow-head disease. Dis Aquat Org $17: 145-157$

Flegel TM, Sriurairatana S, Wongteerasupaya C, Boonsaeng V, Panyim S, Withyachumnarnkul W (1995) Progress in characterization and control of yellow-head virus of Penaeus monodon. In: Browdy CL, Hopkins JS (eds) Swimming through troubled water, proceedings of the special session on shrimp farming. World Aquaculture Society, Baton Rouge, LA, p 76-83

Hanson KW, Hanson J, Aubert H, Redman RM, Lightner DV (1997) A new RNA-friendly fixative for the preservation of penaeid shrimp samples for virological assay using CDNA probes. $I$ Virol Methods 66:227-236

Lightner DV (ed) (1996) A handbook of shrimp pathology and diagnostic procedures for diseases of cultured penaeid shrimp. World Aquaculture Society, Baton Rouge, LA

Lu Y, Tapay LM, Loh PC, Brock JA, Gose RB (1995) Distribution of yellow-head virus in selected tissues and organs of penaeid shrimp Penaeus vannamei. Dis Aquat Org 23: $7-70$ 
Murphy FA, Faquet CM, Bishop DHL, Ghabrial SA, Jarvis AW, Martelli GP, Summers MD (1995) Classification and nomenclature of viruses. Arch Virol Suppl 10:1-586

Nadala ECB Jr, Tapay LM, Loh PC (1997) Yellow-head virus: a rhabdovirus-like pathogen of penaeid shrimp. Dis Aquat Org 31:141-146

Sambrock J, Fritsch EF, Maniatis T (1989) Molecular cloning - a laboratory manual. Cold Spring Harbor Laboratory Press, Cold Spring Harbor, NY

Spann KM, Vickers JE, Lester RJG (1995) Lymphoid organ virus of Penaeus monodon from Australia. Dis Aquat Org $23: 127-134$

Editorial responsibility: Timothy Flegel,

Bangkok, Thailand
Spann KM, Cowley JA, Walker PJ, Lester RJG (1997) A yellow-head-like virus from penaeus monodon cultured in Australia. Dis Aquat Org 31:169-179

Wongteerasupaya $C$, Sriurairatana $S$, Vickers JE, Anutara A, Boonsaeng $V$, Panyim S, Tassanakajon A, Withachumnarnkul B, Flegel TW (1995) Yellow-head virus of Penaeus monodon is an RNA virus. Dis Aquat Org 22: $45-50$

Wongteerasupaya $C$. Tonchuea $W$, Boonsaeng $V$, Panyim S, Tassanakajon A, Withyachumnarnkul B, Flegel TW (1997) Detection of yellow-head virus (YHV) of penaeus by RTPCR amplification. Dis Aquat Org 31:181-186

Submitted: June 26, 1998; Accepted: November 10, 1998 Proofs received from author(s): February 22, 1999 